\title{
Fadama Iii Project And Output Performance Of Agricultural Enterprises: An Empirical Evaluation
}

\author{
Uduakobong S. Inam, Ph.D \\ Department of Economics \\ Faculty of Social Sciences \\ University of Uyo, Uyo, Akwa Ibom State, Nigeria \\ Etim Augustine Effiong \\ Department of Economics \\ Faculty of Social Sciences \\ University of Uyo, Uyo, Akwa Ibom State, Nigeria
}

\begin{abstract}
This paper evaluates the impact of the Fadama III Project on output performance of agricultural enterprises of the beneficiaries in Akwa Ibom State, Nigeria. The study employed the Survey method wherein Questionnaire was administered and interview held. Data collected were analysed using Tables, Percentages and Chi-Square $\left(\mathrm{X}^{2}\right)$ statistical method. Findings revealed that Fadama III project impacted positively on the beneficiaries in Akwa Ibom State as it contributed to the increase in the output performance of beneficiaries. This further contributed immensely to increased access to finances and a remarkable increase in the income of the beneficiaries. The study recommends among others, that government, relevant agencies and stakeholders should sustain the Fadama III project to ensure food security in the society and also for the benefit of the rural poor who are mostly engaged in agricultural activities in order to increase their ouput and improve their incomes.
\end{abstract}

\section{INTRODUCTION}

Societies have defined themselves by the way and degree in which they have succeeded in increasing agricultural production (FAO, 2004). Agricultural production requires a lot of activities that needs value addition with the ultimate intention of increasing the economic value of the final product. Various governments especially of developing economies have been adopting programmes and policies which are formulated to take cognizance of these value addition and marketing of farm outputs to encourage farmers in their production process such that food security is guaranteed and their livelihood is such that they live above subsistence or absolute poverty.In line with this development, Ja'afar-Furo, Bello, Mshelia, and Hammanyaji (2011) stressed that developing countries should rapidly transform their agriculture and massively embark on holistic food production system which involves processing and clearly defined channels of appropriate marketing in order to provide sustainable avenues for income generation for farmers.

Development economists have focused on how agriculture can best contribute to overall economic growth and modernization. Kuznets (1964) noted that agriculture made four contributions to economic development; the product contribution of inputs for industry such as textiles and processing of food, the foreign exchange contribution of using agricultural export revenues to import capital equipment; the market contribution of rising rural income creating more demand for consumer products, and the factors market contribution divided into labour contribution and capital contribution (Meller, 1986; Ghatak, 1987; Timmer, 1988 and Kuznet, 1964). Today, development economists share the consensus that agriculture has 
been assumed to play a passive and supportive role in economic development whereas the agricultural sector in particular and the rural economy in general must play an indispensable part in any overall strategy of economic progress especially in the low-income developing economies..

It could then be asked from the foregoing: how can total agricultural output and productivity per capita be substantially increased in a manner that will directly benefit the average small farmer and the poor rural dweller while providing sufficient food surplus to promote food security and support a growing urban industrial sector? Majority of the world's extreme poor are involved in agricultural activities. The ability of agricultural production to keep pace with world population growth has been impressive defying some neo-malthusian predictions that global food shortage would have emerged by now.

A research by International Food Policy Research Institute (IFPRI) points to the fact that a wide range of successful agricultural programmes have reduced hunger while raising agricultural activity over the last several decades (IFPRI, 2009; Wik, Pingl and Broca, 2007). Despite the increase in agricultural production around the world, critics are of the view that the progress has been uneven. This position is predicated on the fact that the United Nations Food and Agriculture Organization (FAO) has repeatedly warned that food production is on the decline given the fact that 270 million out of about 750 million Africans suffer some form of malnutrition associated with inadequate food supplies (Sczpanik, 1970).

In Nigeria, several programmes have always been introduced by successive government over the years with the hope that the farmers and the poor would immensely benefit from such laudable intentions in terms of income generation through improved production. The Nigerian food problem demanded an urgent development of the nation's water resources for irrigation, hence the introduction of the scheme 'Fadama' after the River Basin Development Authority. The word 'FADAMA' is an Hausa word for 'irrigable land'. The first National Fadama Development Project (NFDP I) was designed in the early 1990s to promote simple low-cost improved irrigation technology under World Bank financing (Nwachukwu and Igbokwe, 2012). The main objective of the NFDP I was to sustainably increase the incomes of Fadama users through expansion of farm and non-farm activities with value-added output. The programme was introduced in twelve States which were Adamawa, Akwa Ibom, Bauchi, Gombe, Imo, Kaduna, Kebbi, Lagos, Niger, Ogun, Oyo and Taraba including the Federal Capital Territory (FCT). The Project adopted Community-Driven Development (CDD) approach with extensive participation of stakeholders at early stage of the project. It focused mainly on crop production whereas downstream activities such as processing, preservation and marketing were largely neglected.

Fadama III was introduced after Fadama I and II had been completed. Like the first and second schemes, Fadama III also adopted the CDD approach such that beneficiaries were the main drivers of the scheme. Local Community members under the umbrella of Fadama Community Association (FCAs) and Fadama User Groups (FUGs) oversee the design and implementation of the project to improve their livelihoods by increasing income-generating activities. The scheme established standardized procedures and steps to guide the local people on how they could take part in the decision-making process. The project has six main components which are capacity building, local governance and communication; small-scale community-owned infrastructure; advisory service and input support development; support to ADPs, sponsored research and on-farm demonstration; asset acquisition for individual FUG/Economic Interest Group; project management, monitoring and evaluation. 


\section{Theoretical Framework}

\section{LITERATURE REVIEW}

Agriculture could be said to emanate using anthropological and archeological evidences other than scientific facts. Such facts include artefacts of ancient farming tools and remains of wild grains (Gallery of Agriculture, 2009). It is possible later that a primitive tribe may have discovered a vigorous plant, the seeds harvested for food although it was also understood that some were deliberately sown to ensure supply for the next season. Several theories some of which include the Physiocrats, Arthur Lewis two sector model, Rostow Stages of Growth etc had been advanced to shed light on the historical development of agriculture. Theoretically, growth in agriculture is a key engine for growth, not least to start a growth process in preindustrial economies (Dercon and Douglas, 2004).

The physiocrats laid emphasis on agriculture in the development of an economy away from mercantilists that emphasized trade and commerce. The source of national wealth was essentially seen in agriculture. They believed that the fate of the economy is regulated by productivity in agriculture and its surplus is diffused through the system in a network of transactions. The agricultural sector, to the physiocrats, is the only genuinely productive sector of the economy and the generator of surplus upon which all depends. Agriculture is that kind of activity which links labour, land or soil, live animals, plants, solar energy and so on. The general idea is that the proprietors of land contribute to production by expenses on improvement of land and by advances to maintain the cultivators. The cultivators in turn, are to procure a surplus over and above all these expenses. This is the net product which goes to the land owners by way of rent. All in all, agriculture's primary purpose was to provide sufficient low-priced food and manpower to the expanding industrial economy (Todaro and Smith,2011). Lewis two sector model is a theory of development that places heavy emphasis on rapid industrial growth with agricultural sector fuelling the industrial expansion by means of its cheap food and surplus labour.

\section{Empirical Literature Review}

Bindlish and Evensen (1997) used cross countries data of 30 countries in sub-saharan Africa to test the effectiveness of $\mathrm{T} \& \mathrm{~V}$ in agricultural extension programmes. From their data analysis, they concluded that the experience of Kenya and Burkina Faso indicate that T\&V management enhances the effectiveness of extension and that such programmes supported agricultural growth and produced high returns on investment. Ashley and Maxwell (2001) reviewed the Washington Consensus on Food, Agriculture and Rural Development. Their findings showed that rural areas were changing with respect to demography, diversification and strengthening of links to national and global economies. They recommended that agriculture should be strengthened as engine of rural development; small farms should be made to non-farm rural community, and that there should be a new thinking on poverty, participation and governance.

Alabi and Osagie (2006) investigated the amount of income generated by increased output expectation by the NDE crop farming programme in Edo State. Data obtained from forty participants surveyed were analyzed using percentage and profit margin. The result showed that the returns management of NDE arable crop farming were positive, indicating that arable cropping is profitable. It was also found that the earning of school leavers in NDE is higher than the earning of their counterparts in the civil service. It was recommended that sufficient loans be granted to farmers as long as there is guarantee that they will use it for agricultural purpose. Mangoel, Ezeokeke, Anyanwu and Okoro (2012) have that agricultural sector contributes enormously to the nation's GDP with job creation, as it accounts for about $90 \%$ of jobs in the country. To them, the agricultural sector contributes to the development of the 
economy in four major ways; product contribution, factor contribution, market contribution and foreign exchange.

Ja'afar-Furo et al (2011) on their study to evaluate the role of Fadama III in improving the output performance of Fadama User Groups (FUGs) through yield per acre, agro-processing facility and storage accessibility in Adamawa State, found that the most popular choice of economic venture among the FUGs was maize/corn, rice processing machines and collectively, the FUGs recorded $10.54 \%$ increase in income from sales/services rendered in terms of value addition on agricultural commodities, whereas, about $15 \%$ had access to market information using modern methods.

\section{Research Design}

\section{RESEARCH METHODOLOGY}

The study adopted the survey research method and this was desirable since the study was nonexperimental. The design would enable the researcher to gather both the primary and secondary data needed to guide the study.

\section{Population/Sample}

The population of the study consists of all Fadama Community Associations (FCAs) and Fadama User Groups (FUGs) in the 20 participating local government areas (LGAs) in Akwa Ibom State. 5 FUGs from the FCAs in each of the LGAs were selected making a total of 30 FUGs and ten (10) members of each FUG were also randomly chosen making up 300 respondents. The six LGAs selected for the study were: Uyo, Ibesikpo Asutan, Oron, Mkpat Enin, Ikot Ekpene and Etim Ekpo.

\section{Data Collection Instruments}

The instruments used for data collection were well structured questionnaires designed to obtain answers from the respondent. All the items in the questionnaire were closed-ended with multiple options such as Yes or No and Undecided, to indicate all available possibilities of response on the subject. Interview was also conducted with the respondents.

\section{Analytical Techniques}

Data collected from the survey were analyzed using Tables and Percentages. Chi-square $\left(\mathrm{X}^{2}\right)$ statistical method was also employed to test the hypothesis formulated in order to test the degree of independence between the variables.

The formula for the chi-square $\left(\mathrm{X}^{2}\right)$ is $\mathrm{X}^{2}=\sum \frac{(\mathrm{O}-\mathrm{E})^{2}}{\mathrm{E}}$

where: $\mathrm{O}=$ Observed value; $\mathrm{E}=$ Expressed value;

Data was analysed based on the null hypothesis $\left(\mathrm{H}_{0}\right)$ : Fadama III Project has no impact on the output performance of agricultural enterprises in Akwa Ibom State. 5 percent level of significance was used to test the hypothesis of the study with the degree of freedom calculated thus: $\mathrm{DF}=(\mathrm{R}-1)(\mathrm{C}-1)$; where $\mathrm{R}=$ row, $\mathrm{C}$-column and $\mathrm{DF}$ - degree of freedom. The $(\mathrm{R}-1)$ means row total minus one, i.e. $\left(R_{t}-1\right)$, while $(C-1)$ means column total minus one, i.e., $\left(C_{t}-1\right)$. The analysis used the calculated value to compare with the table value and thus if the table value is greater than the calculated value, it means that the null hypothesis $\left(\mathrm{H}_{0}\right)$ be accepted while rejecting the alternative hypothesis (H1) otherwise the reverse is the case.

\section{DATA PRESENTATION AND ANALYSIS}

In order to facilitate the actual conduct of the research, a total of three hundred (300) 
questionnaires were distributed to the beneficiaries comprising of Fadama Community Association and Fadama User Groups as respondents. Two hundred and ninety (290) representing $97 \%$ of the questionnaires were returned by the respondents showing a very high percentage of response. Of the returned questionnaires, five were wrongly filled as some of the respondents are not educated and vested with the subject. Therefore, the analysis is based on two hundred and eighty five correctly answered questionnaires.

The first section is on the respondents' personal data such as sex, age, educational qualification and the respondent's line of occupation. The second section required the respondents to give answers that bothered mainly on the study. Chi-square $\left(\mathrm{X}^{2}\right)$ method of analysis was used to test the hypotheses formulated for the study, while simple Tables and Percentages were used mainly for the first part of the questions. Questions $1-8$ with options such as Yes, No and Undecided was used to test the hypotheses.

\section{Analysis Of Personal Demographic Data for Fadama Community Association And Fadama User Groups in Akwa Ibom State}

Table 4.1: Sex distribution of Respondents

\begin{tabular}{|l|l|l|}
\hline SEX & NO. OF RESPONDENTS & PERCENTAGE OF RESPONDENTS (\%) \\
\hline FEMALE & 165 & 58 \\
\hline MALE & 120 & 42 \\
\hline TOTAL & 285 & 100 \\
\hline
\end{tabular}

Source: Field Survey, 2016

Table 4.1 shows respondents' sex distribution. Of the two hundred and eighty five respondents that returned the questionnaires used for the study, one hundred and sixty five (165) or fifty eight percent (58\%) were female while one hundred and twenty (120) or forty two percent (42\%) were male.

Table 4.2: Age distribution of Respondents

\begin{tabular}{|l|l|l|}
\hline AGE GROUPING & NO. OF RESPONDENTS & PERCENTAGE OF RESPONDENTS (\%) \\
\hline $26-35$ & 68 & 23 \\
\hline $36-45$ & 96 & 34 \\
\hline $46-55$ & 85 & 30 \\
\hline 56 AND ABOVE & 36 & 13 \\
\hline TOTAL & 285 & 100 \\
\hline
\end{tabular}

Source: Field Survey, 2016

Table 4.2 shows age distribution of respondents. Of the two hundred and eighty five (285) respondents, sixty eight or $23 \%$ were of the age bracket $26-35$, ninety six (96) or thirty four percent (34\%) were of age bracket 36 - 45, eighty five (85) or thirty percent (30\%) were of the age bracket 46 - 55, while thirty six (36) or thirteen percent (13\%) were of the age bracket 56 and above. 
Table 4.3: Educational qualification of Respondents

\begin{tabular}{|l|l|l|}
\hline AGE GROUPING & NO. OF RESPONDENTS & $\begin{array}{l}\text { PERCENTAGE } \\
\text { RESPONDENTS (\%) }\end{array}$ \\
\hline No Formal Education & - & 0 \\
\hline First School Leaving Certificate & 58 & 20 \\
\hline GCE O/L, WASC or its equivalent & 82 & 29 \\
\hline A/L or ND or it equivalents & - & 0 \\
\hline HND, B.Sc or its equivalent & 106 & 37 \\
\hline Post Graduate (MA), M.Sc) & 39 & 14 \\
\hline Post Graduate (Ph. D) & - & 0 \\
\hline TOTAL & 285 & 100 \\
\hline
\end{tabular}

Source: Field Survey, 2016

In order to get a clearer overview of educational qualification of the respondents, table 4.3 presents seven (7) level of qualification. There is no respondent with no formal education, A/L or ND or it equivalents as well as Post Graduate (Ph. D) levels of qualification. 58(20\%) respondents representing had First School Leaving Certificate, 82(29\%) respondents representing had GCE 0/L, WASC or its equivalent. 106 (37\%) of the respondents had HND, B.Sc or its equivalent. while 39 (14\%) of the respondents had Post Graduate (MA), M.Sc).

4.1.2a Analysis of Respondents on Questionnaires

\begin{tabular}{|l|l|l|l|l|}
\hline$\underline{\text { S/N }}$ & QUESTIONS & $\underline{\text { YES }}$ & $\underline{\text { NO }}$ & $\underline{\text { UNDECIDED }}$ \\
\hline$\underline{1 .}$ & $\begin{array}{l}\text { Has there been any increase (improvement) in the output } \\
\text { of your business? }\end{array}$ & $\underline{134}$ & $\underline{88}$ & $\underline{63}$ \\
\hline$\underline{2}$ & Do you have problem of pest and diseases? & $\underline{75}$ & $\underline{139}$ & $\underline{71}$ \\
\hline$\underline{3}$ & $\begin{array}{l}\text { Has there been any monitoring team to know whether the } \\
\text { farm is producing according to expectation? }\end{array}$ & $\underline{184}$ & $\underline{51}$ & $\underline{50}$ \\
\hline$\underline{4}$ & $\begin{array}{l}\text { Do you have any idea about the expected quality of your } \\
\text { products in terms of seedling, soil type, and general } \\
\text { management? }\end{array}$ & $\underline{160}$ & $\underline{71}$ & $\underline{54}$ \\
\hline$\underline{5}$ & $\begin{array}{l}\text { Do you have enough provision for irrigation facilities for } \\
\text { your produce? }\end{array}$ & $\underline{95}$ & $\underline{110}$ & $\underline{80}$ \\
\hline$\underline{6 .}$ & $\begin{array}{l}\text { Has there been any great improvement in the general } \\
\text { profitability of the business since you started with the } \\
\text { Fadama III scheme? }\end{array}$ & $\underline{122}$ & $\underline{76}$ & $\underline{87}$ \\
\hline$\underline{7 .}$ & Do you need storage facilities for your product? & $\underline{180}$ & $\underline{80}$ & $\underline{25}$ \\
\hline$\underline{8}$. & $\begin{array}{l}\text { If yes, do you have any form of storage facilities for your } \\
\text { products? }\end{array}$ & $\underline{70}$ & $\underline{97}$ & $\underline{13}$ \\
\hline
\end{tabular}

On question 1(the respondents view on whether they have had increases and improvements in the output of the business), 134(47\%) of the respondents agreed while $88(31 \%)$ disagreed to the opinion that there has been improvement in the output of the business since they started with the scheme. 63(22\%) were indifferent. On question 2(the respondents view on whether they do have problem of pest and diseases), 75(26\%) of the respondents agreed that there is problem of pest and diseases in their establishment. 139(49\%) disagreed and claimed that they do not have problem of pest and diseases. 71(25\%) were indifferent to the opinion. On question 3(the respondents view on whether there has been any monitoring team to know whether the farm is producing according to expectation), 184(65\%) of the respondent agreed with the opinion that there has been a monitoring team to know whether the farm is producing according to expectations. 51(18\%) of the respondents disagreed with the opinion that there has been monitoring team to know whether the farm is producing according to expectation. 
$50(17 \%)$ was indifferent to the opinion.

On question 4(the respondents view on whether the respondents have any idea about the expected quality of their products in terms of seedlings, soil type and generational management), $160(56 \%)$ of the respondent agreed while $71(25 \%)$ of the respondents disagreed and claimed that they do not have idea about the expected quality of their product in terms of seedlings, soil type and general management and 54(19\%) were indifferent. On question 5(the respondents view on whether they have enough provision for irrigation facilities for their produce), 95(33\%) of the respondent agreed with the opinion while $110(39 \%)$ of the respondents disagreed with the opinion that provision is made for irrigation for the produce. $80(28 \%)$ was indifferent to the opinion.

On question 6(the respondents view on whether there has been great improvement in the general profitability of the business since they started with Fadama III scheme), 122(43\%) of the respondents agreed to the assertion that there has been great improvement in the general profitability of the business since they started with the scheme while $76(27 \%)$ of the respondents disagreed to the opinion and $87(30 \%)$ were indifferent. On question 7 (the respondents view on whether the beneficiaries have need for storage facilities for the products), $180(63 \%)$ of the respondents agreed that they need storage facilities for their products. $80(28 \%)$ of the respondents were in disagreement that they need storage facilities. $25(9 \%)$ were indifferent. On question 8(the respondents view on whether they have any form of storage facilities for their products), $70(39 \%)$ of the respondents were in the affirmative that they have storage facilities for their products. 97(54\%) of the respondents were in disagreement to the assertion while 13(7\%) were indifferent.

\section{Test of Hypotheses}

The Questions in Table 4.1.2 were used to test the hypothesis of this study that: Fadama III Project has no impact on the output performance of agricultural enterprises in Akwa Ibom State.

4.1.2b A Summary of Respondents on Questionnaires

\begin{tabular}{|l|l|l|l|l|}
\hline QUESTION & YES & NO & UNDECIDED & TOTAL \\
1 & 134 & 88 & 63 & 285 \\
2 & 75 & 139 & 71 & 285 \\
3 & 184 & 51 & 50 & 285 \\
4 & 160 & 71 & 54 & 285 \\
5 & 95 & 110 & 80 & 285 \\
6 & 122 & 76 & 87 & 285 \\
7 & 180 & 80 & 25 & 285 \\
8 & 70 & 97 & 13 & 180 \\
TOTAL & 1020 & 712 & 443 & 2175 \\
\hline
\end{tabular}

$\mathrm{R} 1 \mathrm{C} 1=\frac{\mathrm{Rt} \times \mathrm{Ct}}{\mathrm{Gt}}=\frac{1020 \times 285}{2175}=\frac{290700}{2175}=133.65$

$\mathrm{R} 2 \mathrm{C} 2=\frac{\mathrm{Rt} \times \mathrm{Ct}}{\mathrm{Gt}}=\frac{712 \times 285}{2175}=\frac{202920}{2175}=93.30$

$\mathrm{R} 3 \mathrm{C} 3=\frac{\mathrm{Rt} \times \mathrm{Ct}}{\mathrm{Gt}}=\frac{443 \times 285}{2175}=\frac{126255}{2175}=58.05$ 
4.1.2c A Table of Calculated Chi-Square

\begin{tabular}{|c|c|c|c|c|c|}
\hline CELL & $\mathbf{0}$ & E & O-E & $(0-E)^{2}$ & $\frac{(0-E)^{2}}{E}$ \\
\hline 1 & 134 & 133.65 & 0.35 & 0.1225 & 0.000 \\
\hline 2 & 88 & 93.30 & -5.3 & 28.09 & 0.301 \\
\hline 3 & 63 & 58.05 & 4.95 & 2.5025 & 0.422 \\
\hline 4 & 75 & 133.65 & -58.65 & 3439.8225 & 25.737 \\
\hline 5 & 139 & 93.30 & 45.7 & 2088.4900 & 22.385 \\
\hline 6 & 71 & 58.05 & 12.95 & 167.7025 & 2.889 \\
\hline 7 & 184 & 133.65 & 50.35 & 2535.1225 & 18.968 \\
\hline 8 & 51 & 93.30 & -42.3 & 1789.29 & 19.178 \\
\hline 9 & 50 & 58.05 & -8.05 & 64.8025 & 1.116 \\
\hline 10 & 160 & 133.65 & 26.35 & 694.3225 & 5.195 \\
\hline 11 & 71 & 93.30 & -22.3 & 497.29 & 5.330 \\
\hline 12 & 54 & 58.05 & -4.05 & 16.4025 & 0.282 \\
\hline 13 & 95 & 133.65 & -38.65 & 1493.8225 & 11.177 \\
\hline 14 & 110 & 93.30 & 16.7 & 278.89 & 2.989 \\
\hline 15 & 80 & 58.05 & 21.95 & 481.8025 & 8.300 \\
\hline 16 & 122 & 133.65 & -11.65 & 135.7225 & 1.015 \\
\hline 17 & 76 & 93.30 & -17.3 & 299.29 & 3.207 \\
\hline 18 & 87 & 58.05 & 28.95 & 838.1025 & 14.437 \\
\hline 19 & 180 & 133.65 & 46.35 & 2148.3225 & 16.074 \\
\hline 20 & 80 & 93.30 & -13.3 & 176.89 & 1.896 \\
\hline 21 & 25 & 58.05 & -33.05 & 1092.3025 & 18.816 \\
\hline 22 & 70 & 133.65 & -63.65 & 4051.3225 & 30.313 \\
\hline 23 & 97 & 93.30 & 3.7 & 13.69 & 0.147 \\
\hline 24 & 13 & 58.05 & -45.05 & 2029.5025 & 34.961 \\
\hline
\end{tabular}

Calculated Value of $\mathrm{X}^{2}=245.135$

Degree of Freedom $(D / F)=(R-1)(C-1)=(8-1)(3-1)=(7)(2)=14$

Table Value at $0.05=23.685$

\section{Decision}

Since the calculated value of $\mathrm{X}^{2}$ which is 245.135 is greater than the table value which is 23.685 ( T-Value $=23.685<$ Calculated Value $=245.135)$, the null hypothesis $\left(\mathrm{H}_{0}\right)$ that says that Fadama III Project has no impact on the output performance of agricultural enterprises in Akwa Ibom State is rejected. This means that the Fadama III scheme has an impact on the output performance of beneficiaries in Akwa Ibom State.

\section{Policy Implication of Findings}

It can be seen from the analysis that the output performance of the agricultural enterprises of Fadama III beneficiaries in Akwa Ibom state improved tremendously following the scheme's intervention. The scheme provided the beneficiaries with: better and high quality seedlings; improved ways of handling pests and diseases; and the knowledge of the type of soil needed for each crop. The Fadama III project has also been able to provide the beneficiaries with productive assets such as farm tools and equipment that when applied will enable larger production methods for higher yields. Thus, the output performance per acre or per square metre improved tremendously. This enhanced food availability thus checking scarcity. The incomes of the beneficiaries improved as well.

From these findings, the policy implications are easily discernible: Government at all levels and 
all stakeholders need to sustain this project for the benefit of the rural poor who are mostly engaged in agricultural activities. For agricultural output to be continually improved, the inputs needed for higher productivity must be made available consistently and in sufficient quantity. Knowledge, information and requisite training on improved farming methods should be made available to beneficiaries. Furthermore, government should facilitate a shift from crude method of farming to mechanised farming as this will guarantee better and higher yields. More interventions of this nature should be instituted and implemented in other sectors for greater and wider impacts on social well being.

\section{SUMMARY, POLICY RECOMMENDATIONS AND CONCLUSION}

This study evaluated the impact of Fadama III Project on output performance of the agricultural enterprises of the beneficiaries in Akwa Ibom State. The study employed the survey method wherein Questionnaire were administered and interview held with respondents. Data were analysed using Tables, Percentages and Chi-square $\left(\mathrm{X}^{2}\right)$ statistical method. The findings revealed that the Fadama III project had enormous impact on the output performance of the agricultural enterprises of the beneficiaries in Akwa Ibom State. It further revelaed that the Fadama III project impacted on the income of the beneficiaries in Akwa Ibom state as their income improved tremendously.

Based on the findings, the study recommends that: government, relevant agencies and stakeholders should sustain the Fadama III project to ensure food security in the society and also for the benefit of the rural poor who are mostly engaged in agricultural activities in order to increase their ouput and improve their incomes; High quality seedlings must be made available to beneficiaries consistently and in sufficient quantity to ensure higher productivity; Knowledge, information and requisite training on improved farming methods should be made available to beneficiaries. Furthermore, government should facilitate a shift from crude method of farming to mechanised farming as this will guarantee better and higher yields. More interventions should be instituted and monitored for greater and wider impacts.

This paper has revealed that the Fadama III project has been a success in Akwa Ibom State. Therefore Government, relevant agencies and stakeholders should attract more of such donor funded projects in the agricultural sector to the state to help drive sustainable output performance for a guaranteed food security. This study has contributed immensely to the body of knowledge in that it has filled the existing gap in the literature. Specifically, there is a paucity of studies of this nature with Akwa Ibom state as a case study. The study however, suffered some limitation such as the lack of accessibility to all the Fadama User Groups in the selected local government areas who participated in the scheme. Furthermore, there is need for researchers in related disciplines to further investigate the sustainability plans of the Fadama III project in Akwa Ibom state and also carry out comparative analysis of the impact of this project on other states of the federation.

In conclusion, it is pertinent to note that food security and sufficiency should be of great concern to a country with a teeming population such as Nigeria. Thus, any effort aimed at improving food sufficiency and security should be seen as laudable and given priority attention. Besides, the role of agriculture in the economic growth and development of any nation need not be over-emphasized. Given that the agricultural sector not only helps in food production, but also provides raw materials for use by industries towards the production of finished goods and is also a major earner of foreign exchange as well as the greatest employer of the rural poor, projects aimed at its growth and development should be promoted, implemented, monitored and sustained. 


\section{References}

Abayomi, Y.O (1997), The Agricultural Sector in Nigeria: The Way Forward “Central Bank of Nigeria Bulletin" 21(3), Lagos.

Ahmed, Y. O. (1993), "Bank of the North pamphlets on Agricultural Financing (various circulars and policy guidelines on Agricultural Financing)" A Paper delivered at a Seminar Organised by the Agricultural Department of Bank of the North.

Ajah, J. and A. K. Peace (2013), Perceptional Evaluation of the Impact of Second National Fadama Project on Gender Income, Output and Decision-Making Power in Abuja, Nigeria. Journal of Sustainable Development, Canadian Center of Science and Education, 6 (12): 92-150.

Dauda, T. O., Asiribo, O. E., Akinbode, S. O., Saka, J. O. and B. F. Salahu (2009), “An Assessment of the Roles of Irrigation Farming in the Millenium Development Goals" African Journal of Agricultural Research, 4 (5): $445-450$

Fakayode, S. B., Omotesho, O. A.Olorunsanya, E, Babatunde, R. O., and Obafemi, A. A. (2012), "Economic Assessment of Fadama Maize Production in Kwara State, Nigeria", Journal of Food and Agriculture, 24 (5): 220 295.

Ike, P. C. (2012), “An Analysis of the Impact of Fadama III Project on Poverty Alleviation in Delta State”, Asian Journal of Agricultural Science 4 (2): 158-164

Ja'afar-Furo, M. R., Bello, M. K., Mshelia, S. I., and D. M. Hammanyaji (2013), "Role of Fadama III in improving the income of Fadama User Groups (FUGs) through Agro-Processing and Market Accessibility in Adamawa State, Nigeria, Journal of Development and Agricultural Economics, 5(4): 129-134.

Manggoel, I., Morris, M., Frennkein, L., Adubi, A., Ehui, S., Nwoko, C., Taiwo, O., Nege, C., Okonji, S. P. and L. Chele (2012), “Agricultural Public Spending in Nigeria” International Food Policy Research Institute, A Discussion Paper 00789.

Oladunni, O. A. (2014), The Impact of Fadama III Project on Rural Household Income in Ogun State, Nigeria: The Propensity Score Matching Approach, International Journal of Applied Biosciences 2, (2): 99-110.

Okolo, D. A. (2004), “Regional Study on Agricultural Support : Nigeria’s Case” being a Special Study Report Prepared for Food and Agricultural Organisation (FAO).

Third National Fadama Development Project (NFDP III), Akwa Ibom State Fadama Coordination Office, Uyo, Implementation Status Report (June 2009 - 2012) for $6^{\text {th }}$ Joint World Bank/FGN Supervision Mission.

World Bank (2013). Report of Project Paper on a Proposed Additional Credit in the amount of SDR 132.6 million to the Federal Republic of Nigeria for the Third National Development (FADAMA III PROJECT), Agriculture and Rural Development Sustainable Development Department, Africa Region, 77809-NG 